\title{
余水路内の連行空気量推定に関する研究 \\ STUDY ON THE QUANTITY OF ENTRAINED AIR ESTIMATION INSIDE THE SPILLWAY
}

\author{
平井祐次郎 1 ・森明巨 $2 \cdot$ 小山俊 3 ・青山信幸 $4 \cdot$ 板倉忠興 5 \\ Yujiro HIRAI, Akio MORI, Suguru KOYAMA, Nobuyuki AOYAMA and Tadaoki ITAKURA \\ 1 正会員 工修 北海道奄力株式会社 総合研究所（T067-0033 北海道江別市対雁 2-1） \\ 2 正会員 工博 北海道大学大学院助手 工学研究科 (T060-8628 北海道札幌市北区北 13 条西 8 丁目) \\ 3 正会員 北海道奄力株式会社 水力発電京極調査事務所（テ044-0101 北海道虬田郡京極町字京極 149） \\ 4 正会員 北奄興業株式会社 土木部（宁060-0031 北海道札幌市中央区北 1 条東 1 丁目 2-5） \\ 5 フェロー会員 工博 北海道大学大学院教授 工学研究科（厂060-8628 北海道札幌市北区北 13 条西 8 丁目）
}

\begin{abstract}
A current inside the spillway becomes the high-speed flow of the open channel in the pipe. It becomes pulsation flow when a ventilation section can't be secured and when an air velocity becomes bigger than the velocity of the current. It is necessary that pulsation flow isn't made to occur because it becomes the problem of the vibration and the noise in this case.

We thought that a ventilation section was secured in the center of the section, with circling, a current is made to fall, by combining the curve which is vertical to the horizontal curve, referring to the research which has a bending part in the horizontal part about the spillway. It was found out that the tendency of the quantity of entrained air varied in the surface of the water shape in the vertical pipe, and that the surface of the water shape in the vertical pipe could be classified in four by the difference in the hydrological regime of the horizontal curve. It became possible that it was predicted pulsation flow and that it was designed suitably by this. As for the tendency of the quantity of entrained air, it was found out that it became the same with the in-situ measurement as a result of the model test.
\end{abstract}

Key Words : spillway, high-speed flow, ventilation section, blockade, quantity of entrained air, pulsation flow, turn drop, combined curve, model test, in-situ measurement

\section{1.はじめに}

流れ込み式水力発電所の発電機緊急停止時には, 発電 用水は余水路を通って河川に放流される．余水路は，地 形及び地質構造等を考慮して, 水平部と鉛直部を組み合 わせて作られ，通常，上部半円下部矩形の管路で，水流 は管内の開水路となるように設計される.

水流は，大きな位置エネルギ一を持つことから高速流 となる. このような水流が水平部と鉛直部を結ぶ屈曲部 では，単純な線形として施工費を少なくする等の理由か ら，水流が鉛直管に衝突して跳子返る構造となっている. このため流れの一部が水平管に逆流することで鉛直管 の通気断面の閉塞が生じやすくなる. 鉛直管閉塞は，管 内を水流によって連行される空気流を遮断する. この結 果，間欠的に空気流が遮断されることになり，脈動流を 誘発する ${ }^{1}$.

連行空気量は, 余水路内で発生する最大の水流速度
（以下，流速）に依存し，通常，鉛直部で最大流速が生じ る. このため, 水平部では流速よりも空気速度(以下, 風速)の方が大きくなり, 通気断面内の圧力变化が生じ, この場合にも脈動流を誘発する 2 .

脈動流は，振動による構造物の耐久性の問題 及ひ騒 音による環境への問題へと繋がっていく. 従って余水路 の設計には，まず通気断面を確保することが重要である. 加えて, 連行空気量を精度良く推定することも必要にな ってくる.

同じ様な流況となる構造物としてダム放流管がある が，余水路は複雑な水路線形となることから，流況や連 行空気量をダム放流管の考え ${ }^{30.40}$.5) に当てはめて精度良 く予測することはできない.

峯田ら ${ }^{8)}$ は，余水路の水平曲線部を対象に模型実験を 用いて, 流速と流積比(水流の流積と余水路断面積との 比，水深比に類似) 及び曲率半径を変化させて，水面形 及び連行空気量を測定した．その結果，流速が大きく， 
かつ曲率半径が小さい時，水流は水平曲線部で余水路断 面方向に旋回することが示された.

立坑型减勢工の実験 であるが，立坑径が余水路高さ (=幅)の 3.5 倍となる立坑と余水路の接合部で水路勾配 が変わり，通気断面の確保が難しいことが考えられた。 そこで先の実験結果を参考に，立坑の接線方向から水流 を流入させて立坑内の水流を旋回しながら落下させ，立 坑中心部で通気断面を確保する方法を考えた。

今回，余水路のうち鉛直管閉塞となる線形について, 水平曲線と組み合わせて鉛直曲線を水流が余水路断面 方向に旋回しながら落下させることにより，余水路中心 部で通気断面を確保する新しい試みを考えた．模型実験 にて水理量を変化させ，連行空気量と鉛直曲線の水面形 を測定し解析した．また，模型実験と現地計測の結果か ら，連行空気量の傾向を検討した．本稿は，これらを報 告するものである.

\section{2. 水理模型実験方法}

\section{（1）模型の概要及ひ水理量}

水理模型実験装置の平面図及び緥断図を图-1に示す. 余水路模型は水流を観察するため，透明アクリル製とし た.

この模型は改造工事計画地点の余水路一部を再現し ており, 水平部及び鉛直曲線部の断面は幅 $10 \mathrm{~cm}$. 高さ 10 $\mathrm{cm}$ の上部半円下部矩形、鉛直管は内径 $12.5 \mathrm{~cm}$ となって いる. 一般の余水路断面が幅 $2 m \times$ 高さ $2 m$ であることか ら，本模型の縮尺は $1 / 20$ 程度となっている.

対象とした計画地点の模型上の水理量が, 流速 $180 \mathrm{~cm} /$ $\mathrm{s}$, 流積比 0.4 , 水平曲線部半径 $125 \mathrm{~cm}$, 鉛直管長さ $125 \mathrm{~cm}$ となることから，実験で与える水理量をを表-1 のとおり とした.この水理量でのフルード数は, 1.9〜4.3 となる.

鉊直曲線は，流速 $180 \mathrm{~cm} / \mathrm{s}$ の水流が放物線を描いて洛

下する場合を想定して作られている.

\section{(2)測定方法}

各水理量の測定方法は以下のとおりである。

流 量：水路模型の上流において電磁流量計 $(\phi 100 \mathrm{~mm})$ にて測定

水 深：余水路模型上流端に設置した水深調節ゲートに て調節。

流 速：流量と流積から求まる平均流速を算出.

水面形：スケールにて水深を直読 測定間隔は $10 \mathrm{~cm}$ と した.

空気量：水平曲線部上流側の空気孔に設置した熱線式風 速計により風速を測定し，これに断面積 $(9 \mathrm{~cm} \times$ $9 \mathrm{~cm})$ を乗じて求めた.

風速は断面を 9 等分した各区分の重心で測定し, 1 測点当たり 30 秒間測定した 300 個のデータの 平均値を用いた。
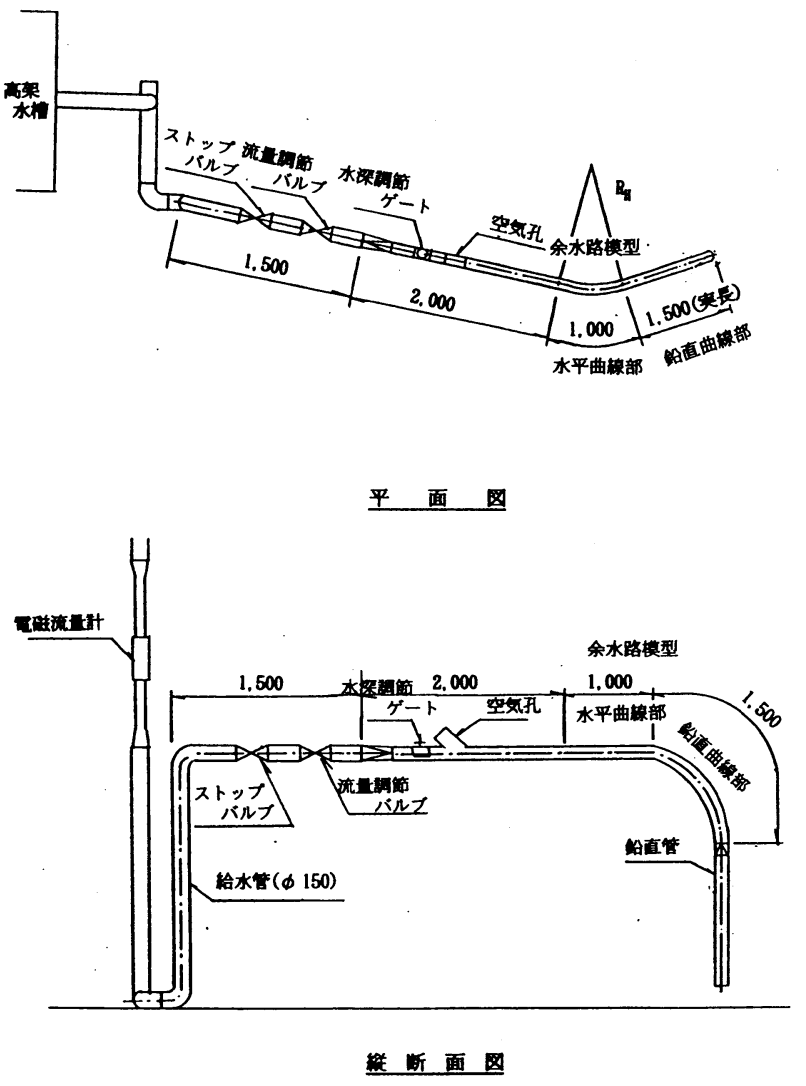

図-1＼cjkstart実験装置概要図

表-1 実策で与えた水理量

\begin{tabular}{|c|c|c|c|}
\hline $\begin{array}{c}\text { 流 速 } \\
\text { (水平部) } \\
V_{\mathbf{v}}(\mathrm{cm} / \mathrm{s})\end{array}$ & $\begin{array}{c}\text { 流積比 } \\
\text { (水平部) } \\
A_{\mathbf{T}} / A_{0}\end{array}$ & $\begin{array}{c}\text { 水平曲線部 } \\
\text { 曲率半径 } \\
\mathrm{R}_{\mathrm{H}}(\mathrm{cm})\end{array}$ & 鉛直管長さ \\
\hline 140 & 0.3 & 100 & 125 \\
\hline 180 & 0.4 & 125 & 185 \\
\hline 220 & 0.5 & 187.5 & \\
\hline & 0.6 & & \\
\hline
\end{tabular}

表-2 現地計測の水理量

\begin{tabular}{|l|c|c|c|c|}
\hline 流量 $\left(\mathrm{m}^{3} / \mathrm{s}\right)$ & 8.0 & 13.8 & 19.8 & 27.5 \\
\hline 水深 $(\mathrm{m})$ & 0.47 & 0.60 & 0.80 & 0.95 \\
\hline 流速 $(\mathrm{m} / \mathrm{s})$ & 7.09 & 9.58 & 10.31 & 12.06 \\
\hline フルード数 & 3.30 & 3.95 & 3.68 & 3.95 \\
\hline
\end{tabular}

\section{3. 現地計測方法の概要}

改造計画地点工事完了時に余水路に水を流して現地計 測を行った ${ }^{8)}$.

流量は，8.0，13.8，19.8，27.5 $\mathrm{m}^{3} / \mathrm{s}$ (最大使用水量) の 4 とおりであり，計測位置を図-2 に示す. No. 2 空気 孔位置の水深は，余水路側壁に貼り付けた量水標をビデ オカメラにて読み取った．流速は，流量と流積から求ま る平均流速を算出した，これらの結果を表-2に示す.

余水路水平部及び鉛直曲線部の断面は，幅 $2.4 \mathrm{~m}$ ，高さ $2.8 \mathrm{~m}$ の上部半円下部矩形である. 

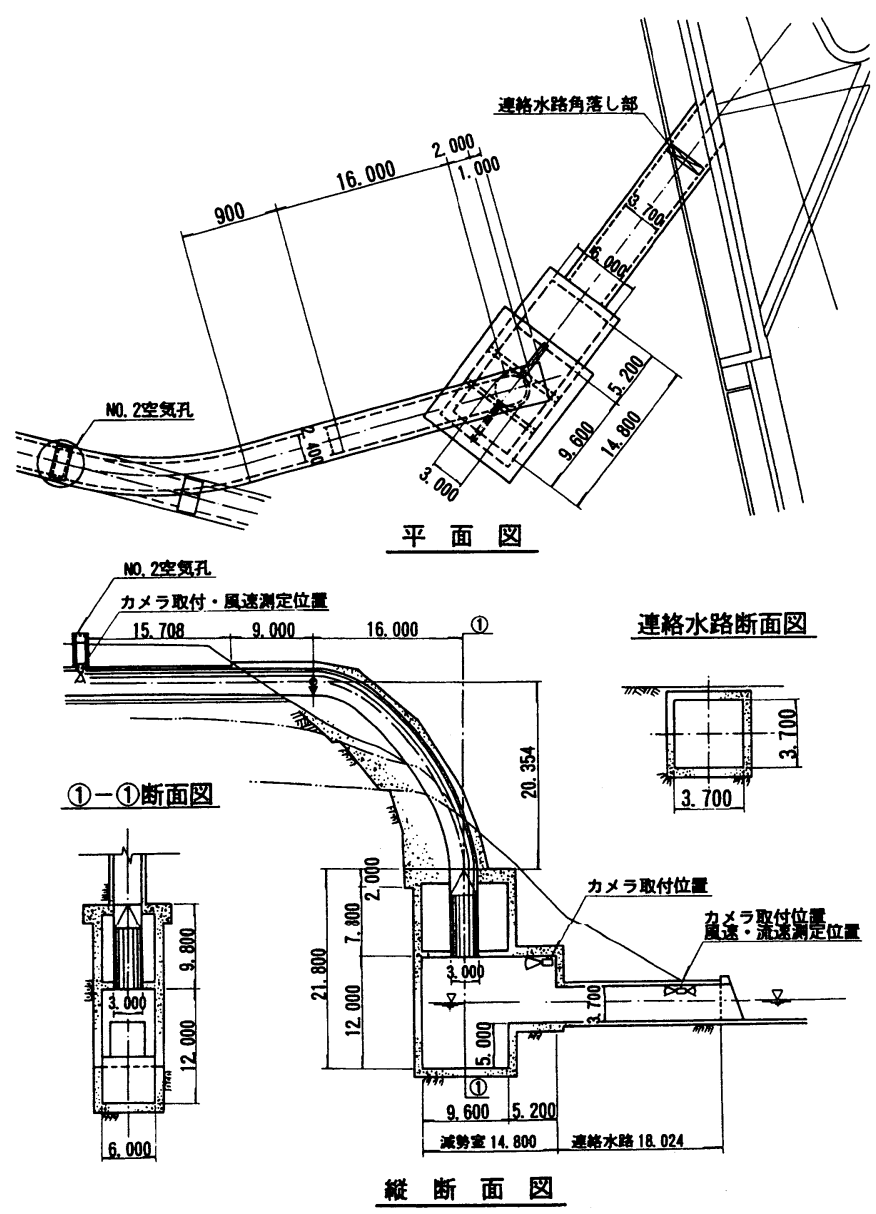

図-2＼cjkstart現地計測位置図

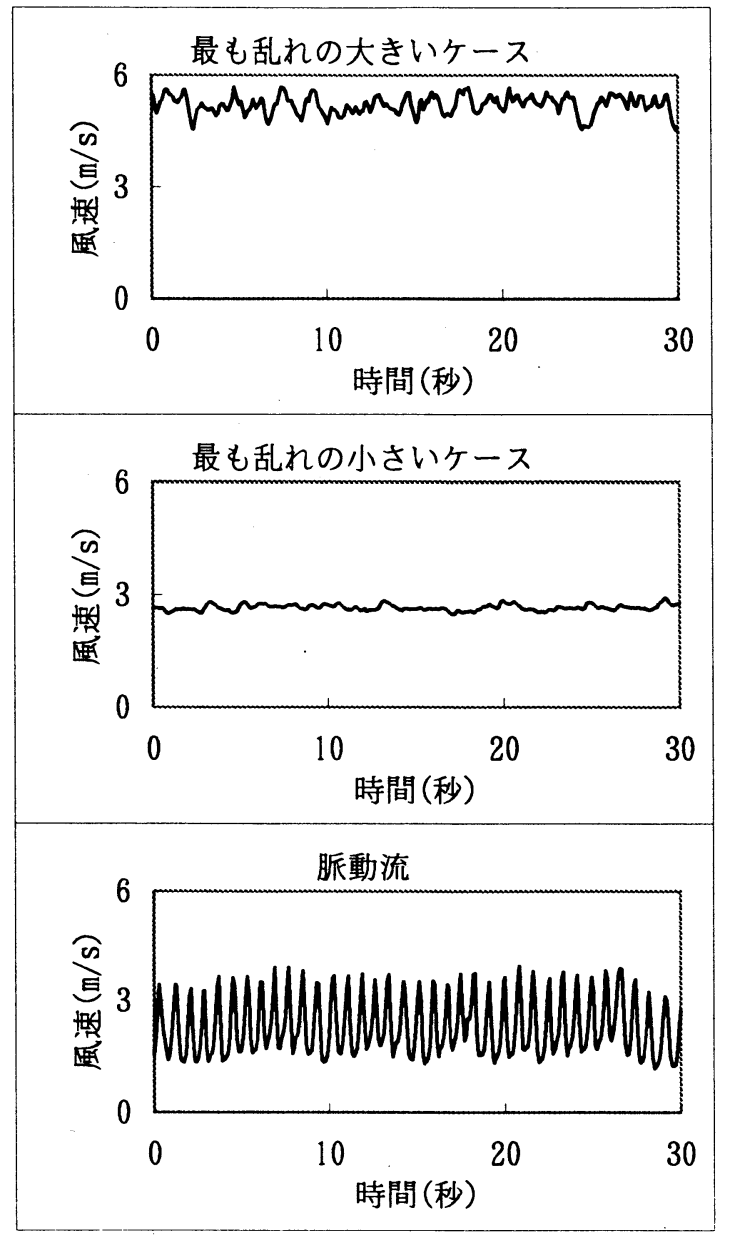

図-3 模型における風速時系列

\section{4. 計測結果}

\section{（1)敛直曲楾部における通気断面}

模型実験において, 空気孔で測定した風速時系列うち 乱れの大きいものと小さいもの，及び脈動流の風速時系 列を図-3に示す．従来の実験から脈動流は，余水路模型 水平部の流積比をおおよそ 0.8 ぐらいにすると発生する ことが示されている. しかしながら当計画地点の余水路 は，水路表面劣化による粗度係数の増加を考虑しても， 流積比が 0.6 以上となることはない，従って，脈動流は 風速のみの測定とした.

脈動流の水面は目視観察で明らかであるが，周期的な 波が発生し，波の頂は水路天端に達していた，風速時系 列を見ると，明瞭な周期性があり，かつ風速変動が大き いことが示されている. 今回与えた水理量では，水流は 脈動流とならず，余水路全区間において通気断面が確保 されていた. しかし，最も乱れの大きいケースの風速時 系列は，余水路鉛直曲線において水路断面中央付近で最 大水位が生じる場合であり，場合によっては脈動流を誘

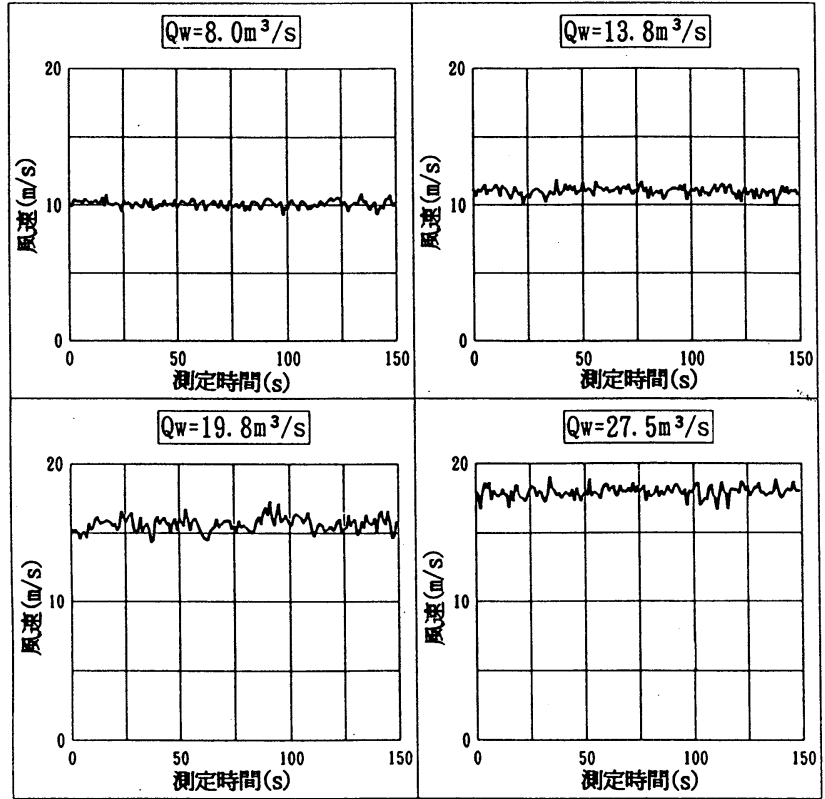

图-4 現地における風速時系列 
発する可能性がある.

現地計測における余水路水平部においては, No. 2 空気 孔に設置したビデオカメラ観察によると，脈動流は生じ ていなかった. またこの位置の風速時系列を図-4に示す が、模型実験で再現した脈動流の時に生じる風速の明瞭 な周期性及び大きな変動は見られなかったことから，現 地においても模型実験と同様，余水路全区間にわたって 通気断面が確保されていたと言える.

\section{（2）模型実験における連行空気量}

実験データを整理比較しても，連行空気量と流速，流 積比，流量 水平部曲率半径との関係は認められなかっ た.

しかし，連行空気量は鉛直管の水面形によって傾向が 異なり，水平曲線部の流況で鉛直管の水面形が決まるこ とが分かった. そこで鉛直管の水面形を(1)旋回無し，(2) 水路断面中央付近で最大水位，(3)左㳬回流（4)右旋回流 の 4 つに分類した. 4 つに分類した水面形を図-5に，鉛 直管長さ $185 \mathrm{~cm}$ における水面形を考㦄した流速と空気量 との関係を図-6に示す。

空気量は水路断面中心付近で最高水位が発生する時に 大きくなる傾向にあり, 右旋回流の時に小さくなる傾向 にあることが分かった，右旋回流は流速が大きくかつ水 平曲線部曲率半径が小さい時に生じ, 水平曲線部の左右 側壁の水位差の最大值は他の水面形と比べて大きくな っている. 従って, 旋回の強い水流となる右旋回流では 連行空気量が少なくなる結果となったことから, 水平管 で脈動流を誘発する可能性が小さく，余水路の最適設計 に反映できるものと考えられる.

次に，鉛直管長さの違いによる空気量の違いを見た。 流量と空気量比 (Qa125/Qa185：鉛直管長さ $125 \mathrm{~cm}$ と $185 \mathrm{~cm}$ の空気量の比)の関係を図-7 に示すが，鉛直管が長い方 が空気量も大きくなる傾向にある. しかし水平管から鉛 直管に移行する水面形によっては詳細な傾向が異なっ ており, 特に旋回流の無い場合にはこの両者の関係は直 線関係になることが分かった.このことから旋回無しと それ以外の流れでは，空気流の構造が大きく異なってい ることが分かった.

\section{（3）模型実験における水面形}

空気量は水平管から鉛直管へ移行する位置の水面形に 影響されることから，余水路水平管内の水面形を予測す ることは重要となる. 図-5を見ると, この位置の水面形 は水平曲線終点の水流の旋回の向きにより決まってく ることから，水平曲線部の水面形の予測が必要である.

射流における台形断面水路及び長方形断面水路の弯曲 部の水面形に対する解析解として, エネルギー式 連続 式及び自由渦の条件式を円筒座標系で求めた Lenau の理 論 ${ }^{9.10)}$ がある. Lenau 式と水理模型実験の測定結果との 比較を図-8 に示す．Lenau 式には水平曲線始点における

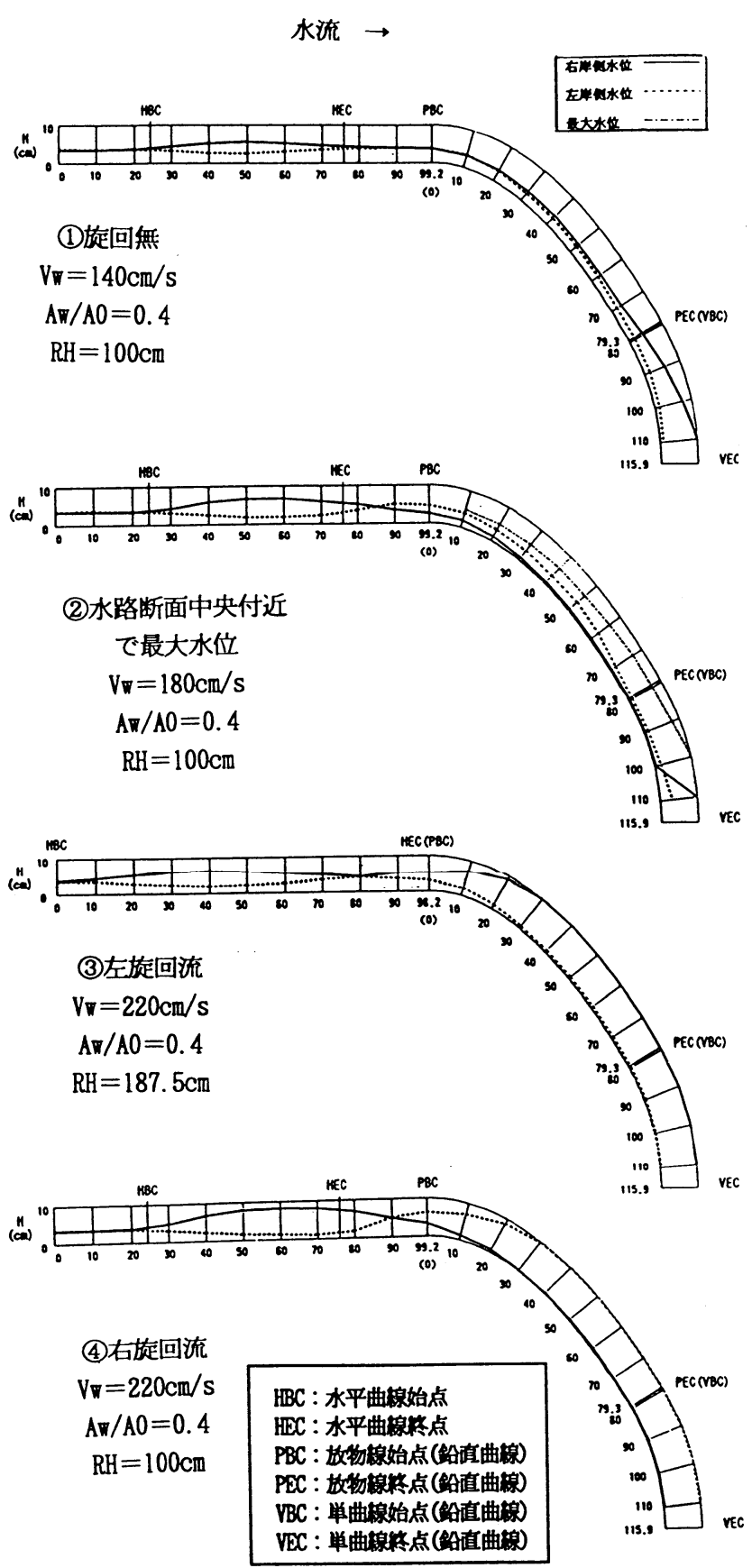

図-5 4つに分類した水面形

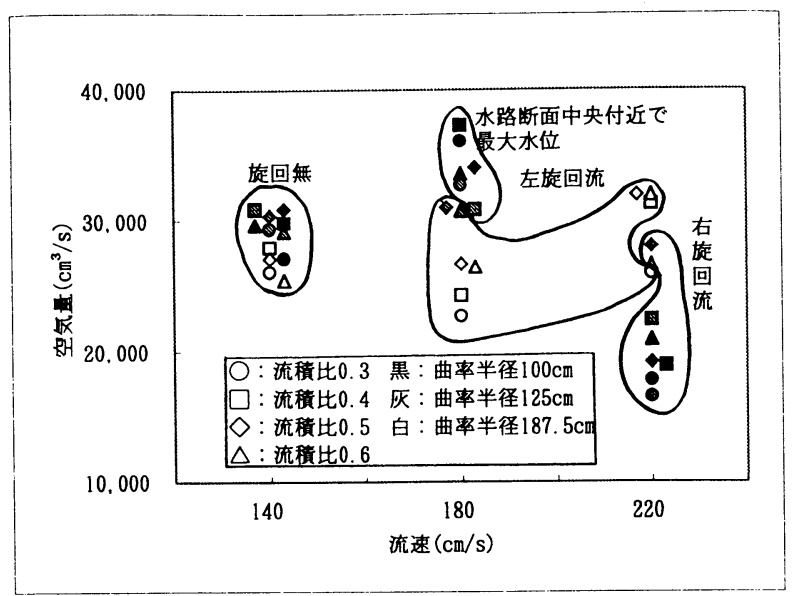

図-6 流速と空気量の関係 


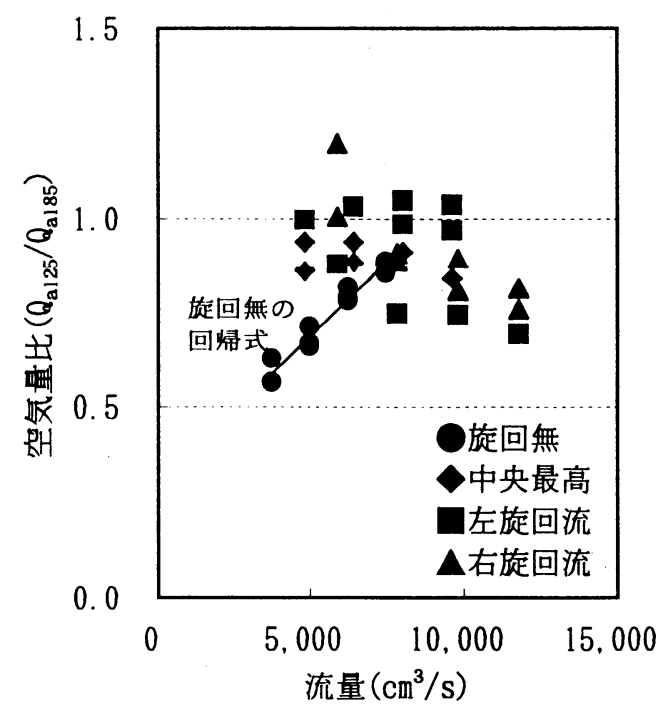

図-7 流量と空気量比の関係

流速及び水深，曲率半径，余水路幅，流下距離を代入し て水面形を求めた.

模型実験の余水路断面は上部半円下部矩形となってい ることから，水面が上部の半円部にくると水面形は Lenau 式とは一致しにくいが, 余水路右岸側(外側)の水 平曲線部始まりの水面変化は同程度となった. また水面 が余水路上部の半円部に達しない水理量では，両者はほ ぼほ致するものとなった.

以上のことから，鉛直管の旋回流は水平曲線部の水面 形を計算する Lenau 式から推定でき, 連行空気量の傾向 を予測できることが分かった.

\section{（4）模型と現地との連行空気量の比較}

現地における鉛直管末端の流況は，減勢室に設置した ビデオカメラを見ると右旋回流であった. №.2 空気孔位 置の水深から流速を計算し，水平曲線部の水面形を Lenau 式で予測すると, 流量が $27.5 \mathrm{~m}^{3} / \mathrm{s}$ では最高水位が 上部半円部になるものの, 流量が $8.0 \mathrm{~m}^{3} / \mathrm{s}$ を除く鉛直管 内の旋回方向は現地計測と同じ右旋回流となることが 計算された. 従って, Lenau 式は現地にも適用できるこ とが分かった.

水平部の流速 V、と Lenau 式で計算した流下方向の水面 形から推定した回転速度 V rot の比は式(1)になる.

$$
\frac{\mathrm{V}_{\mathrm{W}}}{\mathrm{V}_{\mathrm{rot}}}=\frac{\mathrm{gR}_{\mathrm{H}} \sqrt{\mathrm{F}_{\mathrm{r}}^{2}-1}}{\mathrm{~V}_{\mathrm{w}}^{2}}
$$

模型と現地との連行空気量を検討するため, 図-9に示 すように水平部流速と回転速度の比 $V_{w} / V_{\text {rot }}$ と連行空気 量と流量の比 $\mathrm{Q} a / \mathrm{Q}$ 的 の関係を調べた. ここで, 模型の空 気量は鉛直管長さが現地に対応する $125 \mathrm{~cm}$ のケースの值 である.

実験における鉛直管水面形を区別しない全ケースを表

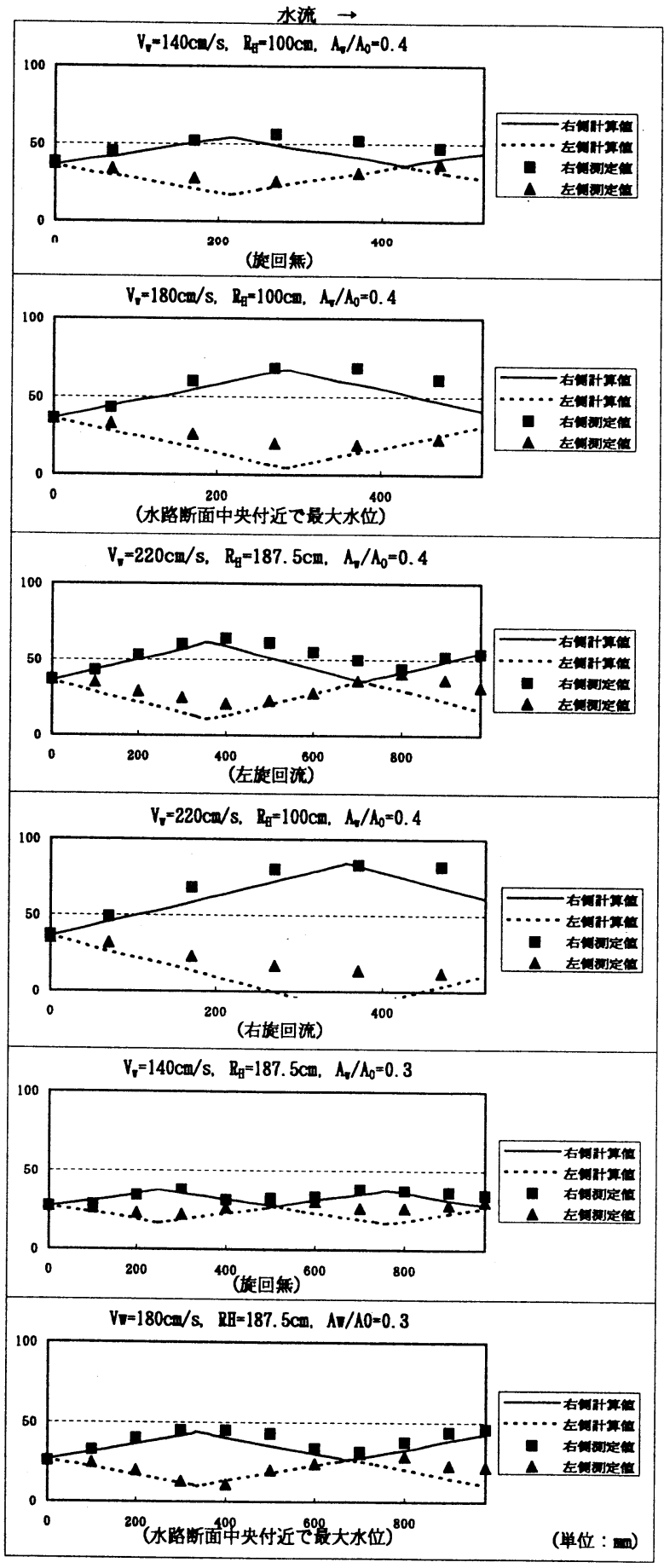

图-8 Lenau 式と計測結果の水平曲線部水面形の比較

示している(a)を見ると，模型と現地との連行空気量は 概ね傾向が似ていることが言える，両者の空気量を更に 詳しく見ると，旋回流となる場合の(b)，(c)では旋回流 とならない場合の (d)，(e)よりも同一傾向にあり，現地 の鉛直管の流況となった右旋回流(b)では最も関係があ ることが分かった．以上のことから，現地の連行空気量 は推定可能であることが分かった. 

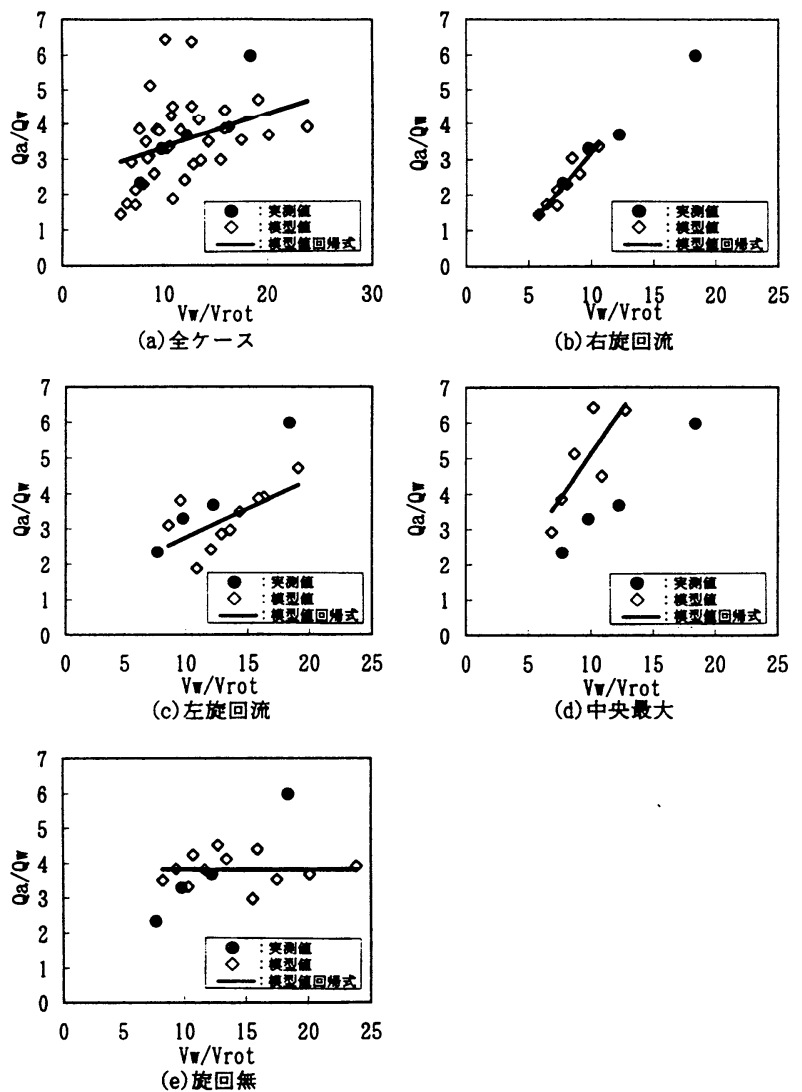

图-9模型と現地との連行空気量の関係

5. まとめ

本研究をまとめると次のようになる.

- 余水路の水平部に弯曲部をもつ過去の研究から, 水 平曲線と鉛直曲線を組み合わせることによって，鉛直 部の水流を旋回落下させて断面中心で通気断面を確保 することを考えた.

- 模型実験にて鉛直部の水面形を 4 つに分類した. 旋 回の強い水流では連行空気量が小さくなるが，断面中 央で最大水位となる水流では連行空気量が大きくなり 脈動流を誘発しやすくなることが分かった。

- 鉛直管における旋回流の向きは水平曲線部の水面 形を計算する Lenau 式から推定でき, 連行空気量の傾 向を予測できる.
- 現地計測と模型実験の結果から, 両者の連行空気量 の䫅向は同じになり, 現地の連行空気量の推定が可能 であることが分かった。

\section{参考文献}

1)福原華一：水力発奄所余水路立坑型减势工の水理設計法，奄 力中央研究所報告，研究報告 U88018，1988

2)竹沢隆一：尾添発電所余水路実験一七ルフ・プライミング (Self - Priming) 防止設計手法一, 奄力土木, №. 183, pp. 31-40. 1983

3)高須修二 中沢䫒司，村岡敬子，井熊 均：ダ么放流管にお ける空気連行流の特性，土木技術資料，28-10，pp. 527-532， 1986

4)高須修二 中沢顕司。村岡敬子，金子 徹: タム放流管にお ける空気連行流の発達過程，士木技術資料，29-8，pp. 437-442, 1987

5)高須修二:ダムと貯水池における気液二相流。タム技術。№. 75 , pp. 26-36, 1992

6)崒田 稔，高橋昌之：高速湾曲水路の設計に関する実験的研 究，土木学会北海道支部論文報告集，第 50 号, pp. 560-565, 1994

7)平井祐次郎，石原英昭，岡島尚司:ヘッドタイプ発奄所の余 水路減勢工水理模型実験，土木学会北海道支部論文報告集， 第 51 号(B)，pp222-227, 1995

8)横辻 幸、平井祐次郎、阿部英夫，青山信幸: 水力発奄所余 水路改造工事に伴う水理模型実験と現地水理計測。奄力土木, No. 271，pp. 8-13, 1997

9) Lenau, C. W. : Supercritical flow in bends of trapezoidal section, Jourmal of the Engineering Mechanics Division, ASCE, Vol.105, No.EMI, pp.43-54, 1979

10)芦田和男，高橋 保，新井宗之：土石流の調節制御に関する 研究(2)，京都大学防災研究所年報，第 24 号 B-2，pp. 251-263. 1979

（1998.9.30 受付） 